\title{
The Isolation of $\lambda$ Phage Carrying DNA from the Histidine and Isoleucine- Valine Regions of the Bacillus subtilis Chromosome
}

\author{
By DEIRDRE A. WALTON, ANNE MOIR, $†$ ROBERT MORSE, $;$ \\ IAN ROBERTS AND DEREK A. SMITH* \\ Department of Genetics, University of Birmingham, Birmingham B15 2TT, UK
}

(Received 19 December 1983)

From a $\lambda \mathrm{gt} W E S$ library of the chromosome of Bacillus subtilis, phages carrying DNA from the hisA and ilv-leu regions were isolated. They were identified by their ability to form complementing plaques on his $B$, ilvC or leuB mutants of Escherichia coli $\mathrm{K} 12$ under selective conditions and in the presence of a helper phage. The his phages complemented E. coli his $A, B$ or $D$ mutations and could transform seven mutations in the his $A$ region of the $B$. subtilis chromosome; each carried a single Eco RI insert of about $8 \cdot 2 \mathrm{~kb}$. Phages complementing $E$. coli $i l v C$ or leuB mutations and carrying the equivalent $B$. subtilis genes $i l v C$ and $l e u C$ transformed a range of mutations in the $B$. subtilis ilv-leu region. The distribution of genetic markers carried by the phages suggests that the entire $i l v-l e u$ cluster from azlA through leuD is covered in the collection of phages obtained and is carried in three EcoRI restriction fragments of approximately $6 \cdot 7,4 \cdot 7$ and $2 \cdot 85 \mathrm{~kb}$.

\section{INTRODUCTION}

The expression of Bacillus subtilis genes cloned in Escherichia coli plasmid or phage vectors can be exploited in selection procedures based on complementation of $E$. coli defects. leuB and pyrE mutations of $E$. coli were complemented in cells lysogenic for a $\lambda$ vector carrying $B$. subtilis DNA (Chi et al., 1978), and the $\beta$-lactamase from Bacillus licheniformis (Brammar et al., 1980) was also expressed in E. coli. Multicopy plasmids carrying the B. subtilis leuC gene can also complement an E. coli leuB mutant (Mahler \& Halvorson, 1977; Nagahari \& Sakaguchi, 1978). Some instability of cloned $B$. subtilis fragments maintained in $B$. subtilis has been encountered, with both phage and plasmid vectors (Kreft \& Hughes, 1982); one advantage of cloning in $E$. coli is that the cloned DNA may be more stable. The fumarase gene of $B$. subtilis was detected in a $\lambda$ library by the formation of microcolonies of weakly complementing lysogens in phage plaques (Moir, 1983). This paper describes the extension of this plaque complementation approach to the isolation of other $B$. subtilis genes. The his and $i l v-l e u$ gene clusters were chosen since not only is their molecular genetics and regulation important but they are also closely linked to spore germination (ger) mutations in the $F$ and $E$ and $H$ loci respectively (Piggot $e$ t al., 1981). Cloning of his and ilv-leu should facilitate the detection of nearby sequences concerned with spore germination.

Very little is known about the genetic control of histidine biosynthesis in B. subtilis. Mutations affecting histidine biosynthesis in $B$. subtilis map either at his $A\left(305^{\circ}\right)$ or his $H\left(205^{\circ}\right)\left(\mathrm{Henner}_{\mathrm{C}}\right.$ Hoch, 1980). The his $H$ locus forms part of a cluster of genes concerned with aromatic amino acid biosynthesis and encodes histidinol phosphate aminotransferase (Nester \& Montoya, 1976; Borenstein \& Ephrati-Elizur, 1969). All other B. subtilis his mutations described map in the his $A$ region (Henner \& Hoch, 1980), so that most of the his genes may be located in this region.

† Present address: Department of Microbiology, University of Sheffield, Sheffield S10 2TN, UK.

$\ddagger$ Present address: Department of Molecular Genetics and Microbiology, University of Massachusetts Medical School, Worcester, MA 01605, USA. 
At least part of this his $A$ gene cluster has been cloned in phage $\rho 11$ (Kawamura et al., 1979). The transduced fragment, however, may have already suffered an internal 1.6 MDal deletion, either during cloning or in the subsequent isolation of plaque-forming phage (Kawamura et al., 1981). The his insert in $\rho 11$ was not stable, and was lost in aproximately $5 \%$ of progeny phage (Mizukami et al., 1980; Kawamura et al., 1981).

The ilv-leu gene cluster is one of the best-characterized potential operons of $B$. subtilis. Genetical and enzymological studies of mutants and an examination of the regulation of expression of the genes (Ward \& Zahler, 1973a,b) have been performed. The isolation of SP $\beta$ defective ilv- and leu-transducing phages facilitated complementation analysis but they were unsuitable for isolation of the DNA of the region (Mackey \& Zahler, 1982). An EcoRI fragment of 4.2 MDal which includes leuC has been cloned on a plasmid vector (Nagahari \& Sakaguchi, 1978) and $\lambda$ (Chi et al., 1978). It carries leuA, $B$ and $C$ alleles, but not ilvB or $i l v C$ (Nagahari \& Sakaguchi, 1978) and since its $l e u A$ and $C$ functions provide only weak complementation even in B. subtilis, it is likely that the natural promoter is absent (Tanaka \& Sakaguchi, 1978).

The plaque-complementation approach has permitted isolation and preliminary characterization of more extensive fragments of DNA from the his $A$ and ilv-leu regions.

\section{METHODS}

Bacteria. The strains of E. coli $\mathrm{K} 12$ and B. subtilis 168 used are listed in Table 1.

Phages. A library constructed by Drs E. Ferrari and J. A. Hoch by ligation into the purified arms of the vector $\lambda \mathrm{gt} W E S . \lambda \mathrm{B}$ (Leder et al., 1977) of a 10-13 kb fraction of the products of partial EcoRI digestion of B. subtilis 168 chromosomal DNA was used. This was propagated once on ED8654 to permit methylation by the $E$. coli $\mathrm{K}$ modification system.

$\lambda i m m^{434}$ Ram54am60 (Moir \& Brammar, 1976) was used as helper phage. Transducing phages carrying $B$. subtilis DNA were named $\lambda \mathrm{BShis,} \lambda \mathrm{BS} i \mathrm{l}$ or $\lambda \mathrm{BS}$ leu according to the selection used to isolate them.

Media. (a) E. coli. Strains were cultured in L-broth and on L-agar (Miller, 1972). Minimal medium for the complementation experiments was M9 salts (Miller, 1972) supplemented with $\mathrm{MgSO}_{4}(10 \mathrm{mM})$, glucose $(0 \cdot 4 \%)$, maltose $(0.4 \%)$ and an amino acid supplement based on the AA medium of Tanaka \& Sakaguchi (1978) which comprised $50 \mu \mathrm{g} \mathrm{ml}^{-1}$ each of alanine, arginine, aspartic acid, cysteine, sodium glutamate, glycine, lysine, methionine, phenylalanine, proline, threonine, tryptophan and tyrosine. In addition, guanine, histidine and leucine were added for $i l v$ selection, isoleucine, leucine and valine for his selection and histidine, isoleucine, valine, thymine (all at $50 \mu \mathrm{g} \mathrm{ml}^{-1}$ ) and thiamin $\left(5 \mu \mathrm{g} \mathrm{ml}^{-1}\right)$ for leu selection. For complementing phage plaques, this medium, further supplemented with 1-2 ml L-broth per litre, was solidified with $1 \%(\mathrm{w} / \mathrm{v})$ Difco Bacto Agar to form bottom agar; top agar was the same medium without L-broth and with $0.65 \%$ Difco Bacto Agar. Phage was propagated and titrated on BBL agar (Parkinson, 1968).

(b) B. subtilis. Nutrient media were Difco Penassay Broth and Potato Glucose Yeast Extract Agar (Dring \& Gould, 1971). Minimal agar (Anagnostopoulos \& Spizizen, 1961) was supplemented with glucose $(0.5 \%)$ and amino acids $\left(50 \mu \mathrm{g} \mathrm{ml}^{-1}\right)$ where required. Culture of cit mutants and selection of $\mathrm{Cit}^{+}$was according to Rutberg \& Hoch (1970).

$\lambda$ phage techniques. Preparation of plating cells, phage propagation, purification and reisolation from single plaques, phage preparation and assay have all been described (Murray et al., 1973). Phages were tested for the presence of suppressible mutations by spotting suspensions (at about $10^{5}$ p.f.u. $\mathrm{ml}^{-1}$ ) on lawns of Ymel, W1485E and W3350, and tested for immunity on lawns of $\operatorname{ED8654}(\lambda)$ and $\operatorname{ED} 8654\left(\lambda \mathrm{imm}^{434}\right)$. Plating cells for complementation experiments were prepared in $\mathrm{L}$ broth + maltose $(0.4 \%)$. Complementation of $E$. coli his, leu or ilv auxotrophs was determined by spotting $10 \mu \mathrm{l}$ of lysates onto lawns of the appropriate strain on supplemented M9 medium; more dense growth of lysogens within the spot after $2-4 \mathrm{~d}$ at $30^{\circ} \mathrm{C}$ indicated complementation.

Complementation of E. coli mutants by mixed infection. This was a modification of the method of Moir (1983). Auxotrophic recipients were strains 4930, JA300 and CGSC2851. The multiplicity of infection by library and helper phages varied as described in Results. Incubation was $4-6 \mathrm{~d}$ at $30^{\circ} \mathrm{C}$, after which complementing plaques or clusters of microcolonies could be observed. Transducing phages were purified by one or two further cycles of plaque formation on selective and one on non-selective medium. Phage lysates sufficiently concentrated for use as donor in transformation could be prepared from suspensions of single complementing plaques by plating $0 \cdot 1-$ $0.3 \mathrm{ml}$ with strain ED8654 on L-agar.

Transformation. Transformation of $B$. subtilis was as described previously (Anagnostopoulos \& Spizizen, 1961; Warburg \& Moir, 1981). $\lambda$ hybrid phages were used directly in transformation by substituting up to $0.1 \mathrm{ml}$ lysate for $0.1 \mathrm{ml}$ DNA (Ferrari et al., 1981). The spore germination (Ger) phenotype was scored by the tetrazolium overlay method (Trowsdale \& Smith, 1975; Lafferty \& Moir, 1977). 
Table 1. Bacterial strains

Strain Genotype

Source

Reference

E. coli $\mathrm{K} 12$

$4930 \quad$ hisB463 $\lambda^{-} \mathrm{F}^{-}$

5388

hisA323 $\lambda$ - HfrG6

6401

his D4758 $\lambda^{-} \mathrm{F}^{-}$

CGSC2851

proA2 aroA357 his4 ilvC7 argE3

thi-1 lacYl galK2 $\mathrm{xyl}-7 \mathrm{mtl}-2$

trf-3 tsx-358 supE44

CV 437

CV522

CV526

ED8654

JA300

W1485E

W3350

leuA371 $\Delta$ (pro-lac) thi $\lambda^{-} \mathrm{F}^{-}$

leuC222 $\mathrm{F}^{+}$

leuD101 $\mathrm{F}^{+}$

supE supF hsdR $R^{-} M^{+} S^{+}$met trpR

trp thi thr thy leuB6 hsdR hsdM

supE

sup ${ }^{\circ}$

Ymel

supF

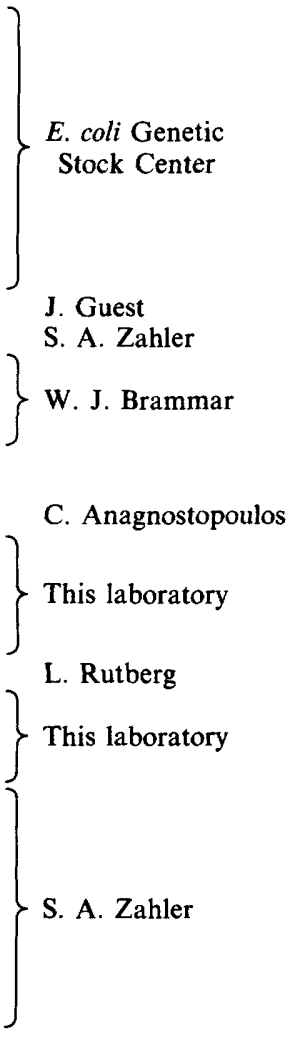

Struhl et al. (1976)

Goldschmidt et al. (1970)

B. subtilis 168

1477

1604

hisAl cysB3 trpC3

$\operatorname{trp} C 2$

leuA8 gerE36

ilvBAI gerE36

ilvB2 gerE36

citF83 leuC2

hisA1 gerF 21 trpC2

hisAl gerF99 trpC2

leuB 16 gerHl

hisA3 trpC2

hisA10 trpC2

ilvB2 leuB16 trpC2

leuD117 trpC2

hisAll trpC2

hisA697 trpC2

hisASII trpC2

hisA677 trpC2

Moir (1981)

Moir (1981)
Murray et al. (1977)

CU431

CU511

CU677

DNA preparation. For initial restriction mapping of some phages the method for isolation of $\lambda$ DNA was that of Sammons \& Anagnostopoulos (1982). Large-scale preparations were made by the liquid lysate method of Loenen

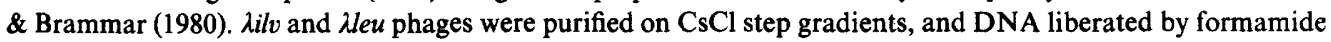
(Davis et al., 1980). Ahis and Mleu phages were treated with RNAase and DNAase and precipitated with polyethylene glycol 6000 . After $15 \mathrm{~h}$ at $4{ }^{\circ} \mathrm{C}$, the precipitate was centrifuged at $10000 \mathrm{~g}(20 \mathrm{~min})$ and the pellet resuspended in $5 \mathrm{ml} 50 \mathrm{~mm}$-Tris/ $\mathrm{HCl}+20 \mathrm{~mm}$-EDTA and $0 \cdot 1 \% \mathrm{SDS}$ at $\mathrm{pH} 7 \cdot 5$. The polyethylene glycol was extracted with an equal volume of chloroform, the supernatant centrifuged at $65000 \mathrm{~g}(1 \mathrm{~h})$ and the pellet resuspended in $1.5 \mathrm{ml}$ of the same Tris buffer. DNA was purified by phenol extraction (Murray et al., 1977) and precipitated twice in two volumes of chilled ethanol $\left(-20^{\circ} \mathrm{C}\right)$ before resuspension in $200-500 \mu 1$ buffer $(100 \mathrm{mM}-$ Tris/ $\mathrm{HCl} \mathrm{pH} 7 \cdot 2+5 \mathrm{~mm}-\mathrm{MgCl}_{2}$ and $50 \mathrm{~mm}-\mathrm{NaCl}$ ).

B. subtilis chromosomal DNA for transformation was prepared by the method of Marmur (1961).

Restriction enzymes. Eco RI and BamHI (Bethesda Research Laboratories) were used according to the manufacturer's instructions.

Gel electrophoresis. Electrophoresis of DNA fragments in agarose gels was as described by Moir (1983).

\section{RESULTS}

\section{Isolation of transducing phages}

Complementation of a mutation in $E$. coli by $\lambda$ hybrid phage carrying Bacillus DNA can be detected either by the production of lysogenic transductants (Chi et al., 1978; Brammar et al., 1980 ) or by the increased growth of lysogens within plaques (Moir, 1983). The latter method has the advantage that even if individual lysogens grow poorly they may be detected as clusters of microcolonies in the centre of plaques. The helper phage $\lambda$ imm $^{434}$ Ram54am60 complements mutations in essential $\lambda$ genes $W, E$ and $S$ and provides homology for integration of the $\lambda \mathrm{gt} W E S$ 
prophage (Moir, 1983). Transducing plaques on a lawn of auxotrophic cells (Franklin, 1971) can appear as lysogen-filled; surrounding cells may be cross-fed, so that the edges of the plaque can be discerned.

Mixed infection of the histidine (hisB) auxotroph 4930 gave seven his-complementing plaques ( $\lambda \mathrm{BShis} A \mathrm{I}-\mathrm{VII}$ inclusive) when $2 \times 10^{7}$ cells were infected with library and helper phages at multiplicities of infection of 7 and 14 respectively. A second experiment yielded two hiscomplementing plaques when $2 \times 10^{7}$ cells were infected with library and helper phages at multiplicities of infection of 0.5 and 1.4 respectively. Phages derived from one of these plaques ( $\lambda \mathrm{BSh}$ is $A \mathrm{VIII})$ were studied further.

$\lambda$ BSleu phages were isolated from a complementation experiment in which JA300 cells were infected at a multiplicity of 1 with library and 3 with helper phage. A $10 \mu \mathrm{l} \mathrm{sample} \mathrm{of} \mathrm{the} \mathrm{mixture}$ containing $3 \times 10^{6}$ infected cells was plated on selective medium with $0 \cdot 1-0.2 \mathrm{ml}$ of plating cells $\left(10^{9} \mathrm{ml}^{-1}\right)$. From this inoculum eight clusters of microcolonies were obtained, five of which were in clearly visible plaques. Phages isolated from all eight transformed strain CU267 to leu $B^{+}$. In this selection a second type of more weakly complementing activity was detected at a 10 -fold greater frequency. These plaques contained phages unable to transform $B$. subtilis leu mutations and were not studied further. In an analogous experiment, complementation of strain CGSC2851 gave a total of eight ilv-complementing, lysogen-containing plaques from four plates, each seeded with $2.5 \times 10^{6}$ cells infected at a multiplicity of 2 of each type of phage per cell. The frequency of transduction was thus $2.7 \times 10^{-6}-3.5 \times 10^{-7}$ per infected cell across this range of experimental conditions.

Phage isolates were purified by repeating the initial selective procedure and then plating nonselectively. Transducing and non-transducing phages were obtained, as defined by the capacity to transform equivalent $B$. subtilis mutations. Immune specificity alone was insufficient to distinguish them, as recombinants which had exchanged immunity regions were common amongst the progeny phages in the complementing plaques.

\section{Characterization of $\lambda B$ Shis $A$ phages}

All of the eight $\lambda B$ BShis $A$ phages tested complemented $E$. coli his $A 323$ and D4758 mutations in addition to hisB463. They also all transformed seven $B$. subtilis his mutations which map in the his $A$ region (S. A. Zahler, personal communication). Representative data for two isolates are shown in Table 2. On the basis of their phage immunity and facility to plaque on $\sup E$ and $F$, sup $E$ and suppressor-free strains, the phages fell into three groups: (i) $\lambda$ BShis $A$ I, II, III, IV, VI and VII - imm ${ }^{\lambda}$ and retaining at least the $S$ mutation; (ii) $\lambda \mathrm{BShis} A \mathrm{~V}-i m m^{434}$ and lacking $W, E$ and $S$ mutations; (iii) $\lambda$ BShisVIII - imm ${ }^{\lambda}$ and retaining either or both the $W$ and $E$ mutations. Recombination with helper phage during the mixed infection could have resulted in such an exchange of markers.

Six of these $\lambda$ BShis isolates (the exceptions being IV and VII) were screened by EcoRI digestion of small-scale DNA preparations. All contained a single EcoRI insert of $8.2 \mathrm{~kb}$, and isolate $\mathrm{V}$ had a restriction pattern consistent with the introduction of an additional Eco RI site in the $i m m^{434}$ region. A simple restriction map was constructed for $\lambda \mathrm{BSh}$ is $A \mathrm{I}$, II and III. The results for each were identical and are summarized in Fig. 1. The right arm of the phage retains the mutations to $E c o$ RI restriction-resistance and the nin5 deletion; the insert contains a single $B a m H I$ target towards its right hand end (showing that its orientation is the same in all three cases), and four HindIII sites.

\section{Characterization of $\lambda B$ Sleu and $\lambda B$ Silv phages}

A large number of isolates were obtained from several leu and ilv complementation experiments. Initial confirmation of transforming activity was obtained by transformation of $B$. subtilis $\mathrm{CU} 267$ to $\mathrm{Leu}^{+}$or $\mathrm{Ilv}^{+}$respectively with impure lysates prepared from complementing plaques. Selection of the alternative marker revealed that 9 out of 12 leu-complementing phages tested also carried $i l v B 2^{+}$and 10 of 27 ilv-complementing phages tested carried leuB16 ${ }^{+}$. All isolates complementing $E$. coli ilv $C$, and thus carrying the entire $i l v C$ gene of $B$. subtilis, also 
Table 2. Transformation of $B$. subtilis auxotrophs by $\lambda B$ Shis, $\lambda B$ Silv and $\lambda B S l e u$ phages

The $B$. subtilis strains were transformed to $\mathrm{His}^{+}, \mathrm{Ilv}^{+}$or $\mathrm{Leu}^{+} ;$using preparations of whole phage as donor. The competence of the recipients was indicated by the efficiency of transformation using control strain 1604 (trpC2) chromosomal DNA.

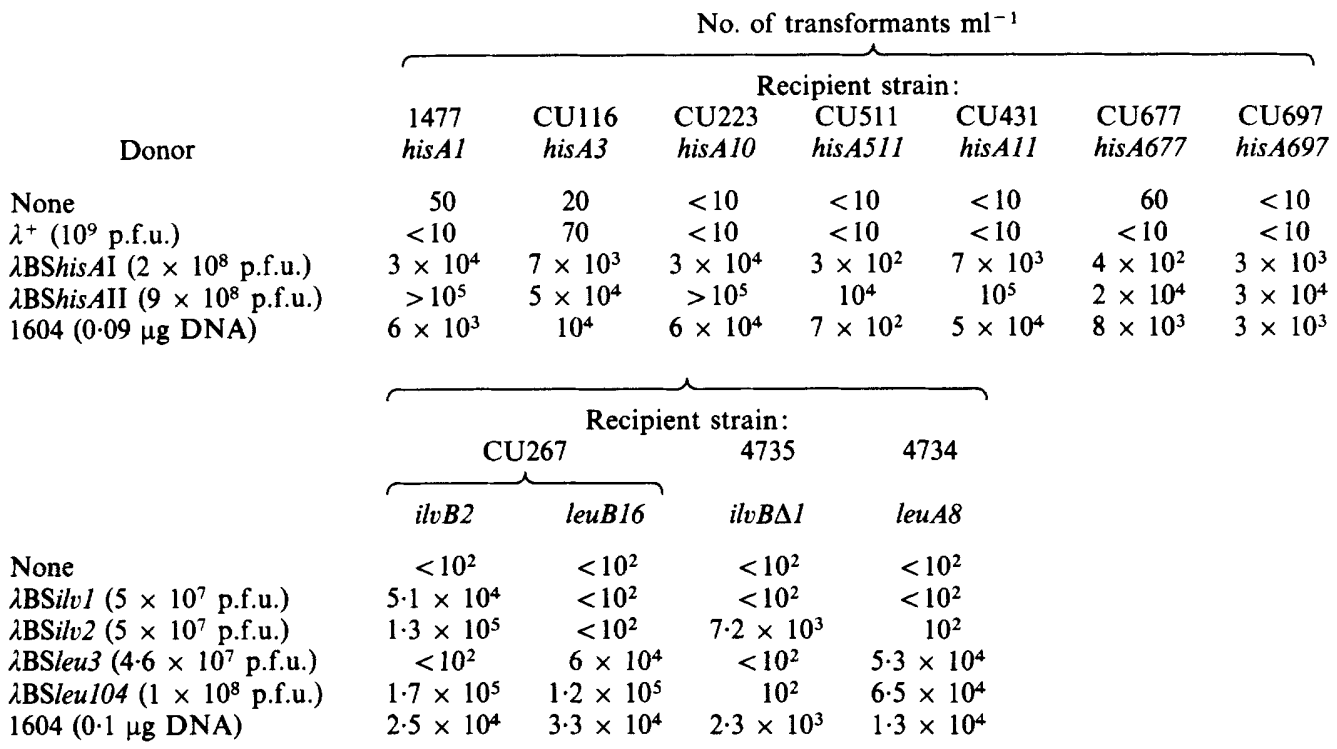

Table 3. Identification of the $B$. subtilis genes carried by $\lambda B$ Sleu and $\lambda B$ Silv phages

$\lambda \mathrm{BS} l e u$ and $\lambda \mathrm{BS} i l v$ phage lysates were used to transform $B$. subtilis or complement $E$. coli leu and ilv auxotrophs. The properties of phages representative of the four types obtained are presented: + , repairs $B$. subtilis lesion by recombination; - , fails to repair $B$. subtilis lesion by recombination; $(+)$, complements equivalent $E$. coli gene; (-), fails to complement equivalent $E$. coli gene.

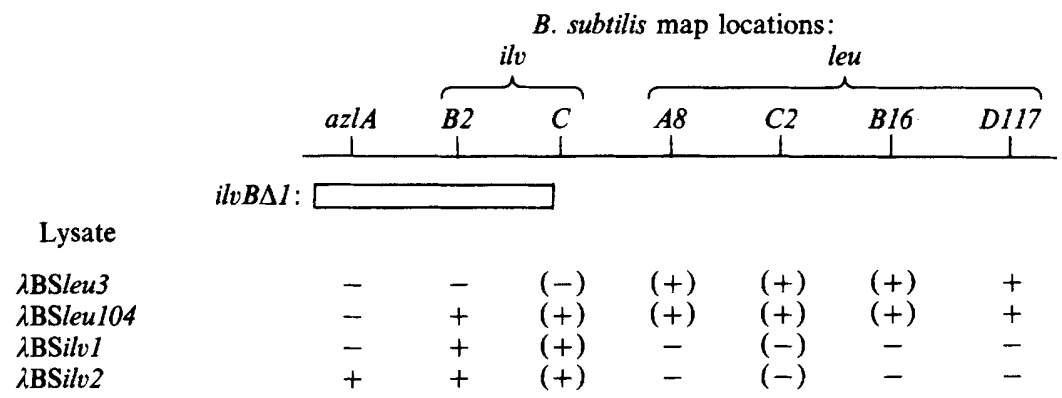

transformed ilvB2. The results of the extensive transformation experiments using purified lysates are shown in Tables 2 and 3.

Crosses with $B$. subtilis strain 4735 determined whether DNA covering the $i l v B \Delta 1$ deletion was present. Seven of the $\lambda B S i l v$ but none of the $\lambda B S$ leu phages tested carried ilvB$B 1^{+}$. Phages complementing the $E$. coli leuB gene must carry a functional copy of the equivalent $B$. subtilis gene leuC. Such $\lambda \mathrm{BS}$ leu isolates could repair by recombination leuA8, leuC2, leuB16 and leuD117 mutations (Table 3). As examples the ability of $\lambda \mathrm{BS} l e u 3$ and $\lambda \mathrm{BS} l e u 104$ to complement the $E$. coli leuA, leuC and leuD defects in strains CV437, CV522 and CV526 were tested. The E. coli leuA and $B$. subtilis leuA genes are equivalent in function (Ward \& Zahler, 1973a). The leuC and leuD genes of $E$. coli encode the two subunits of isopropylmalate isomerase, and it is probable that the $B$. subtilis genes leuB and leuD are both required to encode the equivalent $B$. subtilis enzyme (Mackey \& Zahler, 1982). Complementation of the E. coli leuA and leuC defects was obtained but that of leuD was not detected in the spot test method used. 

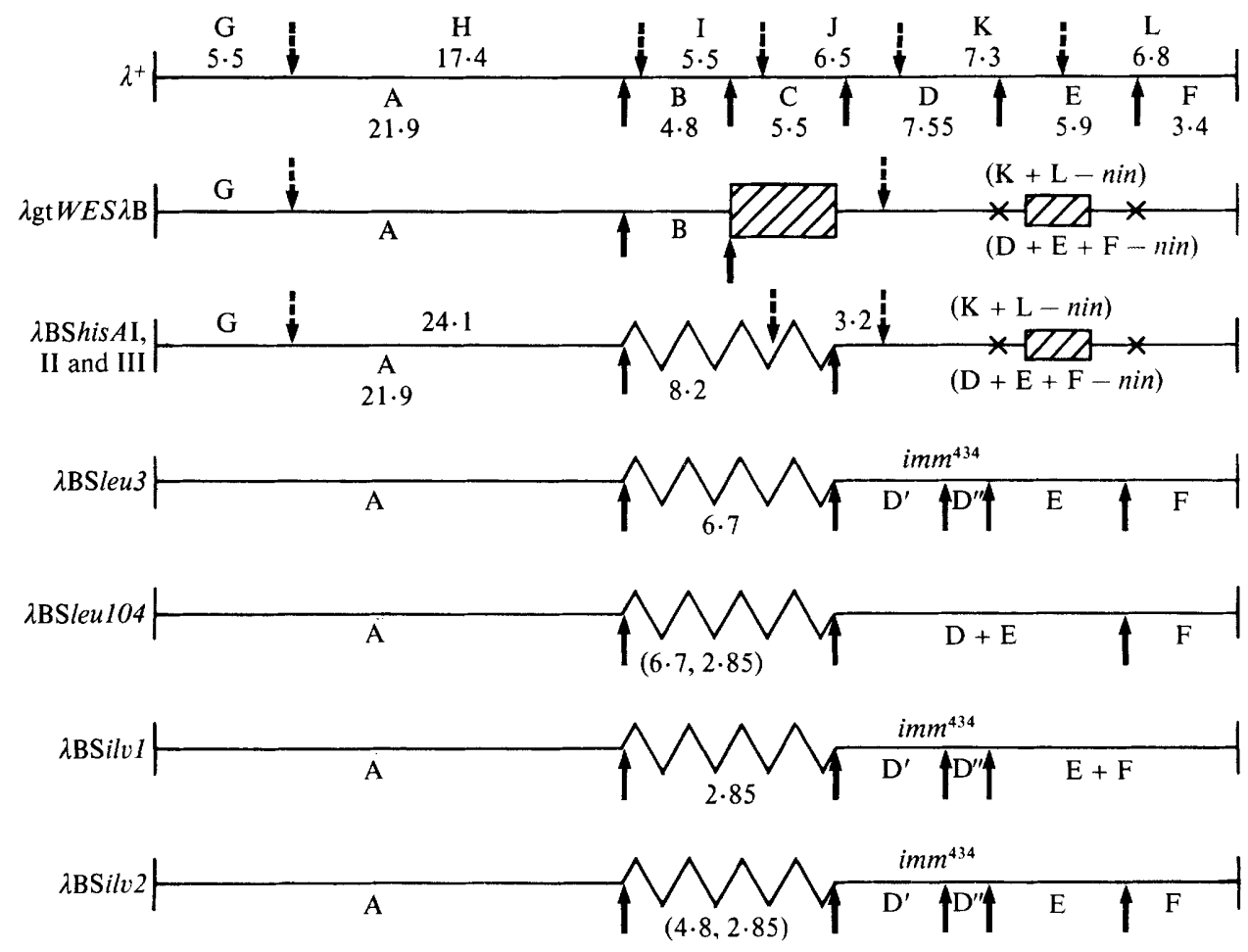

Fig. 1. Simple restriction maps of $\lambda^{+}, \lambda \mathrm{gt} W E S . \lambda \mathrm{B}$ and $\lambda \mathrm{BS}$ his, $\lambda \mathrm{BS} l e u$ and $\lambda \mathrm{BS} i l v$ derivatives. The numbers indicate fragment sizes $(\mathrm{kb})$ which were either estimated by comparison with standards or obtained from a map of $\lambda$ DNA (Szybalski \& Szybalski, 1979). Dashed arrows, BamHI sites; solid arrows, EcoRI sites; hatched areas, deleted regions; zig-zag lines, inserted B. subtilis DNA.

Restriction maps (Fig. 1) of $\lambda$ BSilv and leu phages representative of each of four classes based on patterns of recombination and complementation (Table 3 ) were constructed. The restriction pattern was complicated by the presence of $\mathrm{imm}^{434}, E c o \mathrm{RI}$ restriction targets in the right arm and the nin 5 deletion. $\lambda \mathrm{BSilv1}$, ilv2 and leu 3 were all $\mathrm{imm}^{434} ; \lambda \mathrm{BSilv1}$ and 2 formed plaques only on strains carrying supF and thus still carried at least the $S$ mutation. $\lambda$ BSleu 3 and 104 were able to plaque on supE strains and so they had lost the $S$ mutation.

Correlation of genetic markers with restriction fragments suggests that the $B$. subtilis ilv-leu gene cluster is contained in three $E c o$ RI fragments of approximately $2 \cdot 85,4 \cdot 8$ and $6.7 \mathrm{~kb}$. The entire $i l v C$ gene and at least part of $i l v B$ are contained in the $2.85 \mathrm{~kb} E c o$ RI fragment. Since $\lambda \mathrm{BS} l e u 3$ can complement the equivalent leuA gene of $E$. coli, the Eco RI target is unlikely to be within the coding sequence of the leuA gene. Therefore the EcoRI target forming the junction of the 2.85 and $6.7 \mathrm{~kb}$ fragments must lie between the coding sequences of $i l v C$ and $l e u A$. Genes leu $A, C, B$ and at least part of $D$ are carried on the $6.7 \mathrm{~kb}$ fragment. Phages carrying DNA able to repair the $i l v B \Delta I$ deletion carried the $4.8 \mathrm{~kb}$ fragment; only ilv-transducing phages carrying this fragment complemented $E$. coli sufficiently to permit cross-feeding, which resulted in a halo of growth around the plaques.

Are spore germination genes present on the cloned DNA?

Spores of ger $F$ mutants germinate poorly in a range of germinants and the ger $F$ locus maps very close to the his $A$ region (Moir et al., 1979). gerF 21 is $56 \%$ co-transduced with his $A l$ by phage SPP1 (Warburg, 1981) and gerF99 is $23 \%$ co-transduced with his-11 (D. A. Walton, unpublished). Since the $\lambda \mathrm{BSh}$ his $A$ phages carried an $8.2 \mathrm{~kb} E c o \mathrm{RI}$ insert, it was possible that the gerF gene could be located on it. Strains 4999 and 5176 of B. subtilis were transformed to his $A^{+}$ 
Table 4. Seeking cotransformation of $\mathrm{gerF}^{+}, \mathrm{gerE}^{+}$and $\mathrm{gerH}^{+}$in the cloned DNA

The $B$. subtilis recipients were transformed with $\lambda \mathrm{BSh}$ is, $\lambda \mathrm{BS}$ ilv and $\lambda \mathrm{BS} / e u$ phages to $\mathrm{His}^{+}, \mathrm{Ilv}^{+}$or Leu ${ }^{+}$ and the unselected markers scored.

\begin{tabular}{|c|c|c|c|c|}
\hline Donor & Recipient & Selection & $\begin{array}{l}\text { Unselected } \\
\text { phenotype }\end{array}$ & $\begin{array}{c}\text { Cotransformation } \\
\text { frequency }(\%)\end{array}$ \\
\hline $\begin{array}{l}\text { Chromosomal DNA } \\
\text { גBShisAI-VIII }\end{array}$ & 4999 his $A 1$ gerF 21 & $\begin{array}{l}\mathrm{His}^{+} \\
\mathrm{His}^{+}\end{array}$ & $\begin{array}{l}\mathrm{Ger}^{+} \\
\mathrm{Ger}^{+}\end{array}$ & $\begin{array}{r}38 \\
<1\end{array}$ \\
\hline $\begin{array}{l}\text { Chromosomal DNA } \\
\lambda \text { BShisAI--VIII }\end{array}$ & 5176 hisAl gerF 99 & $\begin{array}{l}\mathrm{His}^{+} \\
\mathrm{His}^{+}\end{array}$ & $\begin{array}{l}\mathrm{Ger}^{+} \\
\mathrm{Ger}^{+}\end{array}$ & $\begin{array}{r}10 \\
<1\end{array}$ \\
\hline $\begin{array}{l}\text { Chromosomal DNA } \\
\lambda \text { BSilv2, 4, 7,11, } \\
18,25 \text { and } 32\end{array}$ & 4735 ilv $B \Delta I$ gerE36 & $\begin{array}{l}\mathrm{Ilv}^{+} \\
\mathrm{Ilv}^{+}\end{array}$ & $\begin{array}{l}\mathrm{Ger}^{+} \\
\mathrm{Ger}^{+}\end{array}$ & $\begin{array}{r}24 \\
<1\end{array}$ \\
\hline $\begin{array}{l}\text { Chromosomal DNA } \\
\lambda \text { BSleu3, 4, } 8 \text { and } \\
101-5 \text { (inclusive) }\end{array}$ & 5185 leuB16 gerH1 & $\begin{array}{l}\mathrm{Leu}^{+} \\
\mathrm{Leu}^{+}\end{array}$ & $\begin{array}{l}\mathrm{Ger}^{+} \\
\mathrm{Ger}^{+}\end{array}$ & $\begin{array}{r}15 \\
<1\end{array}$ \\
\hline $\begin{array}{l}\text { Chromosomal DNA } \\
\text { Chromosomal DNA } \\
\text { ABSleu4 } \\
\text { ABSleul04 }\end{array}$ & CU267 ilvB2 leuB16 & $\begin{array}{l}\mathrm{Ilv}^{+} \\
\mathrm{Leu}^{+} \\
\mathrm{Leu}^{+} \\
\mathrm{Ilv}^{+}\end{array}$ & $\begin{array}{l}\mathrm{Leu}^{+} \\
\mathrm{Ilv}^{+} \\
\mathrm{Ilv}^{+} \\
\mathrm{Leu}^{+}\end{array}$ & $\begin{array}{l}56 \\
53 \\
15 \\
12\end{array}$ \\
\hline
\end{tabular}

by each of the $\lambda \mathrm{BSh}$ his $A$ phages, and at least 100 transformants from each experiment tested for the cotransfer of $\mathrm{gerF} 21^{+}$or $\mathrm{gerF} 99^{+}$. None was observed, although a $38 \%$ co-transformation of gerF $21^{+}$with his $\mathrm{Al}^{+}$was obtained when chromosomal DNA from strain 1604 was used as donor (Table 4).

gerE and gerH mutations map on either side of the $i l v-l e u$ gene cluster (Piggot et al., 1981). Transducing phages carrying $i l v B \Delta I^{+}$carry the $E c o$ RI fragment extending from the gene cluster in the direction of ger $E$. Seven phages were tested (Table 4) for cotransformation of $g e r E^{+}$with ilvB $B^{+}$. None introduced gerE $E^{+}$into $\mathrm{Ilv}^{+}$transformants. Eight phage isolates carrying leuB ${ }^{+}$ failed to cotransform gerH ${ }^{+}$. ilv and leu markers on the cloned DNA were cotransformed at frequencies of $12-15 \%$, which was lower than that observed with chromosomal DNA $(53-56 \%)$. Cotransformation of $\mathrm{gerA1}{ }^{+}$with $\mathrm{cit} \mathrm{G}^{+}{ }^{+}$is likewise reduced from $70 \%$ to $41-46 \%$ as compared with chromosomal DNA when $\lambda$ phages or plasmids carrying these markers are used as donors (Moir \& Smith, 1983; A. Moir, unpublished).

The failure to provide $g e r E^{+}$or $g e r H^{+}$from cloned DNA suggests that it does not extend sufficiently far to include these genes. However, because the cotransformation of markers on cloned DNA is lower than that obtained using chromosomal DNA as donor (Table 4) a failure to detect cotransformed unselected markers is not conclusive proof of their absence. Congression experiments (Moir, 1983) would be definitive. It is unlikely, however, that gerE is present; the $24 \%$ cotransformation of chromosomal ger $E$ with ilvB suggests that it maps some way from ilvB, but it is close to cit $F 83(90 \%$ cotransduced by SPP1 - Moir, 1981). None of the $\lambda$ BSilv phages in Table 4 transformed a citF83 mutant to $\mathrm{Cit}^{+}$(A. Moir, unpublished).

\section{DISCUSSION}

The successful isolation of phages carrying his, ilv and leu genes of $B$. subtilis shows that the ability of these genes cloned in $\lambda$ to be weakly expressed in $E$. coli permits their selection on appropriate media. The method broadly follows the helper approach of Moir (1983) although the selection conditions used here are considerably more stringent and there are some significant differences. Most notably, the frequency of detection of phages complementing the auxotrophic markers was $3 \times 10^{-6}-3 \times 10^{-7}$ per infected cell, whereas that for fumarase-positive clones was approximately $4 \times 10^{-5}$ (Moir, 1983). This lower recovery could reflect a lower concentration of these phages in the pool but either reduced efficiency of complementation of phage functions by helper in infected cells, or poor detection of complementing plaques on a minimal growth medium, or a combination of both of these factors, could be involved. 
The transducing phages obtained that carry particular $B$. subtilis genes, although separately isolated in the selection procedure, are not necessarily independent. For the ilv-leu gene cluster Table 3 shows that a range of isolates carrying overlapping regions were obtained. The genetical and physical data suggest that all the $\lambda \mathrm{BSh}$ his phages isolated carry an identical $8.2 \mathrm{~kb}$ fragment of the $B$. subtilis chromosome. They may have originated from a single insertion event during the initial construction of the library, followed by packing and replication. Alternatively, the constraints on the size of the insert to produce viable phage may have meant that this was the only fragment carrying the particular region selected which could be inserted and that this event occurred many times.

Helper phage was essential for the initial detection of complementing plaques, as no such colony clusters were obtained when it was omitted, although it was unnecessary for complementation during later stages of isolation. Some phages would complement auxotrophic markers in strains lacking nonsense suppressors, or carrying only supE, despite failure of the phage to form plaques on the same strain on rich medium. It may be that during slow growth on selective medium, lysis of cells in the absence of $S$ protein was sufficient to permit cycles of infection and the appearance of barely-visible plaques. The status of $W$ and $E$ mutations on the phages has not been established. Complementation by phages could be observed as the improved growth of small clusters of colonies of individual lysogens within an area of barely discernible lysis. The colonies were generally slow-growing and became mucoid on prolonged incubation.

Expression of cloned genes during lytic growth could have been, in part at least, from phage promoters, but expression in the lysogenic phase, the major indicator in these experiments, is more likely to be initiated from promoters in the cloned DNA. Too little is known of the organization of his genes in $B$. subtilis to be able to say whether the natural promoter has been cloned. For the $i l v-l e u$ cluster, the cloned segment spans sufficient DNA to include a promoter near the regulatory azlA locus upstream of $i l v B$ (Mackey \& Zahler, 1982); this would be consistent with the cross-feeding observed only in phages carrying the $4.8 \mathrm{~kb}\left(\mathrm{ilvB} \Delta \mathrm{I}^{+}\right)$ fragment. Studies of azaleucine-resistant deletions (C. J. Mackey \& S. A. Zahler, personal communication) indicate that the azlA locus and the start of the $i l v B$ gene are within the $4.8 \mathrm{~kb}$ fragment. How expression of $i l v C$ and leu genes from phages lacking this fragment occurs remains to be analysed. The $\lambda \mathrm{BS}$ ilv clones are the first to carry the regulatory region of the ilv-leu gene cluster, and will permit a study of the molecular biology of expression of these genes.

The observation that the $E$. coli leuD mutation was not complemented by $\lambda B S l e u$ phages was unexpected and implies that the $B$. subtilis leuD cistron is not totally contained in the cloned DNA. This would lead to the conclusion that the ability of the $\lambda B S l e u$ phages to complement defects in the $E$. coli leuC cistron would involve the cooperative function of the $E$. coli leuD and $B$. subtilis leuB gene products. Alternative explanations, also involving interaction between heterologous subunits, are possible. For example it is formally possible that leuD is intact in the cloned DNA but that wild-type $E$. coli leuC gene product interferes with the formation or activity of the $B$. subtilis isopropylmalate isomerase complex. This could be explored by testing the complementation of $B$. subtilis leuD mutations by the $6.7 \mathrm{~kb}$ Eco RI fragment cloned in appropriate vectors.

The $8.2 \mathrm{~kb}(4.9 \mathrm{MDal})$ insert in all the $\lambda \mathrm{BS}$ his $A$ phages isolated probably corresponds to the 4.9 MDal fragment identified in an Eco RI digest of $B$. subtilis chromosomal DNA when probed with a $\rho 11$ phis $A^{+}$phage (Kawamura et al., 1981). Indeed, the $\lambda \mathrm{BS}$ his $A \mathrm{II}$ insert hybridizes to fragments of identical size when used to probe an EcoRI digest of $B$. subtilis chromosomal DNA (R. Morse, unpublished). The $\rho 11 \mathrm{phis} A^{+}$phage which had a 3.3 MDal insert and was thought to have suffered a deletion of $B$. subtilis DNA transduced a $B$. subtilis hisAl mutant (Kawamura et $a l ., 1979)$ and carried a single BamHI site towards one end of the insert and two HindIII sites. The $\lambda \mathrm{BShis} A$ phages have three HindIII sites so that the deletion in the $\rho 11 \mathrm{phis} A^{+}$phage may have removed at least one of these sites.

The complementation of the $E$. coli his $A, B$ and $D$ genes by the $\lambda \mathrm{BS}$ his $A$ phages demonstrates that at least some $B$. subtilis his genes can function in $E$. coli. It seems unlikely that apparent complementation resulted from suppression of the $E$. coli mutations as the phages were able to 
transform seven different $B$. subtilis his mutations. These complementation and transformation properties of the $\lambda \mathrm{BSh}$ is phages could not have resulted from phage functions since $\lambda^{+}$did not possess them (Table 2). The $8.2 \mathrm{~kb}$ insert therefore carries gene(s) for at least three histidine biosynthetic enzyme activities, i.e. the equivalents of $E$. coli his $A-N-\left(5^{\prime}\right.$-phospho-Lribosylformimino)-5-amino-1-(5'-phosphoribosyl)-4-imidazolecarboxamide isomerase, his $B$ imidazole-glycerolphosphate dehydratase, and his $D$ - histidinol dehydrogenase. These phages could, therefore, be useful for the study of the genes and regulatory elements controlling histidine biosynthesis in $B$. subtilis.

The his, ilv and leu sequences isolated do not extend into the ger genes mapping nearby. The DNA clones are being used, however, as probes to detect overlapping sequences in other $B$. subtilis chromosomal libraries. The lack of direct selection for ger genes requires such a strategy.

The general approach described in this paper could be adopted to seek phages carrying other biosynthetic genes of $B$. subtilis which would aid comparison of the regulatory systems of $B$. subtilis with those of $E$. coli operons, the control of which is becoming clarified at the molecular level. It need not be restricted to genes in which mutations have been isolated and mapped, as an appropriate $E$. coli mutant is sufficient for the complementation approach. However, direct proof of the nature of the cloned DNA would be necessary, for example by deletion or insertion mutagenesis of the cloned DNA, followed by recombination back into the $B$. subtilis chromosome in order to test the effect of the mutation on the phenotype.

Technical assistance by Mrs Sue Haley and Mrs Joyce Yeomans is gratefully acknowledged. The work was supported by the SERC in the form of a reseach grant to Dr D. A. Smith (D. W.), a Research Fellowship (A. M.) and research studentships (R. M. and I. R.).

\section{REFERENCES}

Anagnostopoulos, C. \& Spizizen, J. (1961). Requirements for transformation in Bacillus subtilis. Journal of Bacteriology 81, 741-746.

Borenstein, S. \& Ephrati-Elizur, E. (1969). Spontaneous release of DNA in sequential genetic order by Bacillus subtilis. Journal of Molecular Biology 45, 137152.

Brammar, W. J., Muir, S. \& McMorris, A. (1980). Molecular cloning of the gene for $\beta$-lactamase of Bacillus licheniformis and its expression in Escherichia coli. Molecular and General Genetics 178, 217224.

ChI, N.-Y. W., Ehrlich, S. D. \& Lederberg, J. (1978). Functional expression of two Bacillus subtilis chromosomal genes in Escherichia coli. Journal of Bacteriology 133, 816-821.

Davis, R. W., Botstein, D. \& Roth, J. R. (1980). Extraction of DNA from phage $\lambda$. In Advanced Bacterial Genetics : a Manual for Genetic Engineering, pp. 106-107. New York: Cold Spring Harbor Laboratory.

DRING, G. J. \& Gould, G. W. (1971). Movement of potassium during L-alanine-initiated germination of Bacillus subtilis spores. In Spore Research 1971, pp. 133-141. Edited by A. N. Barker, G. W. Gould \& J. Wolf. London: Academic Press.

Ferrari, E., Henner, D. \& Hoch, J. A. (1981). Isolation of Bacillus subtilis genes from a Charon 4A library. Journal of Bacteriology 146, 430-432.

Franklin, N. C. (1971). The $\mathbf{N}$ operon of lambda; extent and regulation as observed in fusions to the tryptophan operon of $E$. coli. In The Bacteriophage Lambda, pp. 621-638. Edited by A. D. Hershey. New York: Cold Spring Harbor Laboratory.

Goldschmidt, E. D., CATER, M. S., Matney, T. S.,
Butler, M. A. \& Greene, A. (1970). Genetic analysis of the histidine operon in Escherichia coli K12. Genetics 66, 219-229.

HenNeR, D. J. \& Hoch, J. A. (1980). The Bacillus subtilis chromosome. Microbiological Reviews 44, 57-82.

Kawamura, F., SaIto, H. \& Ikeda, Y. (1979). A method for construction of specialised transducing phage $\rho 11$ of Bacillus subtilis. Gene 5, 87-91.

Kawamura, F., Mizukami, T., Anzai, H. \& Saito, H. (1981). Frequent deletion of Bacillus subtilis chromosomal fragment in artificially constructed p11phis $A^{+}$. FEBS Letters 136, 244-246.

KREFT, J. \& Hughes, C. (1982). Cloning vectors derived from plasmids and phage of Bacillus. In Current Topics in Microbiology and Immunology. 96. Gene Cloning in Organisms other than E. coli, pp. 1-17. Edited by P. H. Hofschneider \& W. Goebel. Berlin: Springer-Verlag.

LAFFERTY, E. \& MoIr, A. (1977). Further studies on conditional germination mutants of Bacillus subtilis 168. In Spore Research 1976, pp. 87-105. Edited by A. N. Barker, J. Wolf, D. J. Ellar, G. J. Dring \& G. W. Gould. London: Academic Press.

Leder, P., TIEMEIER, D. \& ENQUIST, L. (1977). EK2 derivatives of bacteriophage lambda useful in the cloning of DNA from higher organisms: the $\lambda$ gtWES system. Science 196, 175-177.

Loenen, W. A. M. \& Brammar, W. J. (1980). A bacteriophage lambda vector for cloning large DNA fragments made with several restriction enzymes. Gene 20, 249-259.

MACKeY, C. J. \& ZaHLER, S. A. (1982). Insertion of bacteriophage SP $\beta$ into the cit $F$ gene of Bacillus subtilis and specialised transduction of the ilvBC-leu genes. Journal of Bacteriology 151, 1222-1229. 
MaHLER, I. \& Halvorson, H. (1977). Transformation of Escherichia coli and Bacillus subtilis with a hybrid plasmid molecule. Journal of Bacteriology 131, 374377.

MARMUR, J. (1961). A procedure for the isolation of deoxyribonucleic acid from microorganisms. Journal of Molecular Biology 3, 208-218.

MilleR, J. H. (1972), Experiments in Molecular Genetics. New York: Cold Spring Harbor Laboratory.

Mizukami, T., Kawamura, F. \& Saito, H. (1980). Genetic instability of artificially constructed phage $\rho 11$ carrying histidine $\boldsymbol{A}$ gene of Bacillus subtilis. Journal of General and Applied Microbiology 26, 307310.

MoIR, A. (1981). Germination properties of a sporecoat-defective mutant of Bacillus subtilis. Journal of Bacteriology 146, 1106-1116.

MoIR, A. (1983). The isolation of $\lambda$ transducing phages carrying the cit $G$ and ger $A$ genes of Bacillus subtilis. Journal of General Microbiology 129, 303-310.

MoIR, A. \& Brammar, W. J. (1976). The use of specialised transducing phage in the amplification of enzyme production. Molecular and General Genetics 149, 87-99.

MoIR, A. \& SMITH, D. A. (1983). The genetics of spore germination in Bacillus subtilis. In Fundamental and Applied Aspects of Spores, pp. 89-100. Edited by G. J. Dring, D. J. Ellar \& G. W. Gould. London: Academic Press.

Moir, A., Lafferty, E. \& Smith, D. A. (1979). Genetic analysis of spore germination mutants of Bacillus subtilis 168: the correlation of phenotype with map location. Journal of General Microbiology 111, 165-180.

Murray, N. E., Mandura de Ritis, P. \& Foster, L. A. (1973). DNA targets for the Escherichia coli K restriction system analysed genetically in recombinants between phages phi80 and lambda. Molecular and General Genetics 120, 261-281.

Murray, N. E., Brammar, W. J. \& Murray, K. (1977). Lambdoid phages that simplify the recovery of in vitro recombinants. Molecular and General Genetics 150, 53-61.

Nagahari, K. \& SaKaguchi, K. (1978). Cloning of Bacillus subtilis leucine $A, B$ and $C$ genes with Escherichia coli plasmids and expression of the leuC gene in E. coli. Molecular and General Genetics 158, 263-270.

Nester, E. W. \& Montoya, A. L. (1976). An enzyme common to histidine and aromatic acid biosynthesis in Bacillus subtilis. Journal of Bacteriology 126, 699705.

PARKinson, J. S. (1968). Genetics of the left arm of the chromosome of bacteriophage lambda. Genetics $\mathbf{5 9}$, 311-325.

Piggot, P. J., MoIr, A. \& Smith, D. A. (1981). Advances in the genetics of Bacillus subtilis differentiation. In Sporulation and Germination, pp. 29-39. Edited by H. S. Levinson, A. L. Sonenshein \& D. J. Tipper. Washington, DC: American Society for Microbiology.

Rutberg, B. \& Hoch, J. A. (1970). Citric acid cycle: gene-enzyme relationships in Bacillus subtilis. Journal of Bacteriology 104, 826-833.

Sammons, R. L. \& ANAGNostopoulos, C. (1982). Identification of a cloned DNA segment at a junction of chromosome regions involved in rearrangements in the trpE26 strains of Bacillus subtilis. FEMS Microbiology Letters 15, 265-268.

Struhl, K., Cameron, J. R. \& Davis, R. W. (1976). Functional genetic expression of eukaryotic DNA in Escherichia coli. Proceedings of the National Academy of Sciences of the United States of America 73, 14711475.

SzYbalsKi, E. H. \& SzYbalski, W. (1979). A comprehensive molecular map of bacteriophage lambda. Gene 7, 217-270.

TANAKA, T.\& SAKaguchi, K. (1978). Construction of a recombinant plasmid composed of Bacillus subtilis leucine genes and a $\boldsymbol{B}$. subtilis (natto) plasmid: its use as cloning vehicle in $B$. subtilis 168. Molecular and General Genetics 165, 269-276.

Trowsdale, J. \& SMITH, D. A. (1975). Isolation, characterisation and mapping of Bacillus subtilis 168 germination mutants. Journal of Bacteriology 123, 83-95.

WarbURG, R. J. (1981). Some pleiotropic mutations affecting spore germination in Bacillus subtilis 168 . $\mathrm{PhD}$ thesis, University of Birmingham, UK.

Warburg, R. J. \& MoIR, A. (1981). Properties of a mutant of Bacillus subtilis 168 in which spore germination is blocked at a late stage. Journal of General Microbiology 124, 243-253.

WARD, J. B., JR \& ZAHLER, S. A. (1973a). Genetic studies of leucine biosynthesis in Bacillus subtilis. Journal of Bacteriology 116, 719-726.

WARD, J. B., JR. \& ZAHLER, S. A. (1973b). Regulation of leucine biosynthesis in Bacillus subtilis. Journal of Bacteriology 116, 727-735. 